\title{
Glucose and triglyceride excursions following a standardized meal in individuals with diabetes: ELSA-Brasil study
}

\author{
Bárbara P Riboldi ${ }^{1} 2^{*}$, Vivian C Luft ${ }^{1,2}$, Cristina D de Castilhos ${ }^{1}$, Letícia O de Cardoso ${ }^{3}$, Maria I Schmidt ${ }^{1}$,
} Sandhi M Barreto ${ }^{4}$, Maria F de Sander ${ }^{5}$, Sheila M Alvim ${ }^{6}$ and Bruce B Duncan ${ }^{1}$

\begin{abstract}
Objective: To assess glucose and triglyceride excursions 2 hours after the ingestion of a standardized meal and their associations with clinical characteristics and cardiovascular complications in individuals with diabetes.

Research design and methods: Blood samples of 898 subjects with diabetes were collected at fasting and 2 hours after a meal containing $455 \mathrm{kcal}, 14 \mathrm{~g}$ of saturated fat and $47 \mathrm{~g}$ of carbohydrates. Self-reported morbidity, socio-demographic characteristics and clinical measures were obtained by interview and exams performed at the baseline visit of the ELSA-Brasil cohort study.
\end{abstract}

Results: Median (interquartile range, IQR) for fasting glucose was 150.5 (123-198) mg/dL and for fasting triglycerides 140 (103-199) $\mathrm{mg} / \mathrm{dL}$. The median excursion for glucose was 45 (15-76) $\mathrm{mg} / \mathrm{dL}$ and for triglycerides $26(11-45) \mathrm{mg} / \mathrm{dL}$. In multiple linear regression, a greater glucose excursion was associated with higher glycated hemoglobin $(10.7,95 \% \mathrm{Cl}$ 9.1-12.3 mg/dL), duration of diabetes (4.5; $2.6-6.4 \mathrm{mg} / \mathrm{dL}$, per 5 year increase), insulin use (44.4; 31.7-57.1 mg/dL), and age $\left(6.1 ; 2.5-9.6 \mathrm{mg} / \mathrm{dL}\right.$, per 10 year increase); and with lower body mass index $\left(-5.6 ;-8.4--2.8 \mathrm{mg} / \mathrm{dL}\right.$, per $5 \mathrm{~kg} / \mathrm{m}^{2}$ increase). In adjusted logistic regression models, a greater glucose excursion was marginally associated with the presence of cardiovascular comorbidities (coronary heart disease, myocardial infarction and angina) in those with obesity.

Conclusions: A greater postprandial glycemic response to a small meal was positively associated with indicators of a decreased capacity for insulin secretion and negatively associated with obesity. No pattern of response was observed with a greater postprandial triglyceride excursion.

\section{Introduction}

Diabetes prevalence is increasing worldwide, mainly due to the aging of the population and the epidemic rise in obesity [1], the two main determinants of type 2 diabetes. Diets containing high levels of animal fat and a high glycemic index are associated with both diabetes mellitus (DM) and cardiovascular disease (CVD), a major complication of diabetes [2-4]. Hyperglycemia is a major risk factor for the development of chronic microvascular (retinopathy and nephropathy) and macrovascular (ischemic

\footnotetext{
* Correspondence: barbara.riboldi@gmail.com

${ }^{1}$ Graduate Studies Program in Epidemiology, School of Medicine, Federal University of Rio Grande do Sul, Porto Alegre, RS, Brazil

${ }^{2}$ Food and Nutrition Research Center, Hospital de Clínicas de Porto Alegre, Federal University of Rio Grande do Sul, Rua Ramiro Barcelos 2600/419, Porto Alegre, RS 90035-003, Brazil

Full list of author information is available at the end of the article
}

cardiomyopathy, stroke, and peripheral vascular disease) complications [5]. Postprandial hyperglycemia contributes importantly to overall hyperglycemia and cardiovascular complications [6].

A $2 \mathrm{~h}$ post-load plasma glucose during a 75-g OGTT is more predictive of overall mortality than fasting glucose [7]. Postprandial hyperglycemia, measured after breakfast, lunch and dinner, is an independent risk factor for CVD [8] and mortality [9] among individuals with diabetes. Additionally, postprandial hypertriglyceridemia has been shown to be a risk factor for CVD among individuals without diabetes [10] and is associated with an increased intima-media thickness of the carotid artery in individuals with diabetes [11]. However, few large studies have evaluated glucose and triglyceride post-meal excursions in individuals with diabetes, and their association with diabetes comorbidities. 
This study aims to assess glucose and triglyceride excursions 2 hours after the ingestion of a standardized meal and their associations with clinical characteristics and the presence of cardiovascular complications in individuals with diabetes.

\section{Research design and methods}

This is a cross-sectional analysis of 2008-2010 baseline data from the Brazilian Longitudinal Study of Adult Health (ELSA-Brasil), a multicenter cohort study of 15,105 public sector employees (active or retired) in six cities in three different regions of Brazil [12]. Of these, 1496 reported a previous diagnosis of diabetes, and 958 (64\%) performed the meal test. We excluded 46 participants because of incomplete meal ingestion or missing values for fasting or post-meal plasma glucose and triglycerides, and 14 participants reporting diabetes onset before the age of 40 with insulin being their first medication, characteristics suggesting type I diabetes. Thus, the final analysis was performed on 898 diabetic subjects. ELSA-Brasil was approved by the respective Ethics and Research Committee of each participating institution, and participants gave written consent prior to entering the study.

Sociodemographic data, a past medical history of diabetes and other diseases, and drug use were obtained through a standardized interview. Anthropometric data height, weight, waist and hip circumferences and blood pressure - were measured, blood pressure being obtained three times with the mean of the last two measurements used in analyses.

A 12 hour fasting blood sample was drawn by venipuncture in the morning period following standardized procedures for samples collection and processing [13]. Participants were instructed not to use medicines on the morning of examinations until after this collection. The standardized meal was administered shortly thereafter, and an additional sample was drawn 2 hours later. The meal consisted of four slices ( 30 grams) of industrialized toast (Bauducco ${ }^{\circ}$ ), four cubes (20 grams) of processed cheese (Polenghinho ${ }^{\circ}$ ), and a box $(200 \mathrm{ml})$ of an orange-flavored drink $\left(\mathrm{Kapo}^{\circ}\right)$, totaling, according to labels, $454.8 \mathrm{kcal}$, and containing 24.4 grams of lipids (13.8 grams of saturated fat), 46.8 grams of carbohydrates, 12.0 grams of protein, and $570 \mathrm{mg}$ of sodium.

Blood specimens were processed locally and then sent to the central ELSA-Brasil laboratory for analysis. Glucose was determined by the hexokinase enzymatic method. Total cholesterol, triglycerides, HDL-cholesterol and LDLcholesterol were estimated by the enzymatic colorimetric method. Insulin was determined by chemiluminescence (sandwich immunoassay) and C-reactive protein by an automated immunochemical method [14]. Glucose and triglyceride post-load excursions were defined as the difference between the corresponding $2 \mathrm{~h}$ post-load and fasting values.

Raised blood pressure was defined as systolic blood pressure $\geq 130 \mathrm{mmHg}$, a diastolic blood pressure $\geq 85 \mathrm{mmHg}$ [15], or confirmed use of antihypertensive medication [16]; postural hypotension as a decrease of $\geq 20 \mathrm{mmHg}$ for systolic or $\geq 10 \mathrm{mmHg}$ for diastolic blood pressure when changing from supine to standing position [17]. Coronary disease was defined as a history of angina, myocardial infarction, angioplasty or bypass surgery; any cardiovascular complication as coronary disease, heart failure, or stroke. Abdominal obesity was considered present when waist circumference was $>102 \mathrm{~cm}$ for men and $>88 \mathrm{~cm}$ for women; hypertriglyceridemia when triglycerides $>150 \mathrm{mg} / \mathrm{dL}$; and low HDL-cholesterol when HDL-cholesterol was $<40 \mathrm{mg} /$ $\mathrm{dL}$ for men and $<50 \mathrm{mg} / \mathrm{dL}$ for women [16]. Continuous variables were expressed as mean (standard deviation) or median (interquartile range), according to their distribution, with Spearman correlation coefficients being used to assess associations. ANCOVA was used for comparison of glucose and triglyceride excursions between groups with different demographic and clinical characteristics.

Linear regression models were constructed to investigate associations of clinical characteristics with glucose and triglyceride excursions, linearity being assessed using the Box-Tidwell test. Logistic regression models were fitted to investigate associations of glucose and triglyceride excursions with the presence of chronic diseases. Multicollinearity among variables was assessed by the variance inflation factor.

A significance level of 5\% was adopted. Analyses were performed using SAS software (Statistical Analysis System, SAS Institute Inc., Cary, NC), version 9.3.

\section{Results}

Table 1 presents clinical and laboratory characteristics of the 898 participants with diabetes. Of note, median age was 59.5 (54.0 to 65.0) years, and most were overweight $(42.7 \%)$ or obese $(41.8 \%)$. Median duration of diabetes was 6 (3.0-12.0) years, and $15.6 \%$ were using insulin and $76.6 \%$ other medications (principally metformin and sulfonylureas) for diabetes. The median for fasting glucose was 150.5 (123.0 to 198.0$) \mathrm{mg} / \mathrm{dL}$ and for post-load glucose 200.0 (146.0 to 274.0$) \mathrm{mg} / \mathrm{dL}$. The median glucose excursion was $44.0 \mathrm{mg} / \mathrm{dL}$, with interquartile range from 15.0 to $76.0 \mathrm{mg} / \mathrm{dL}$. The median for fasting plasma triglycerides was 140 (103.0 to 199.0$) \mathrm{mg} / \mathrm{dL}$ and for post-load triglycerides 172.0 (128.0 to 237.0$) \mathrm{mg} / \mathrm{dL}$. The median triglyceride excursion was $26.0 \mathrm{mg} / \mathrm{dL}$, with interquartile range from 11.0 to $45.0 \mathrm{mg} / \mathrm{dL}$. Only $16.5 \%$ of participants reported a cardiovascular comorbidity.

The strongest correlations with the post-load glucose excursion were seen with fasting glucose $(r=0.43$, $\mathrm{p}<0.01)$, post-load glucose $(\mathrm{r}=0.83 \mathrm{p}<0.01)$, and 
Table 1 Characteristics of participants with self-reported diabetes who consumed a test meal $(n=898)$

\begin{tabular}{|c|c|c|}
\hline Characteristic & $\begin{array}{l}\text { Median } \\
\text { or } \mathrm{N}\end{array}$ & $\begin{array}{l}\text { Interquartile } \\
\text { range or } \%\end{array}$ \\
\hline Age (years) & 59.5 & $54.0-65.0$ \\
\hline \multicolumn{3}{|l|}{ Race } \\
\hline Black & 220 & $25.1 \%$ \\
\hline Brown ("pardos") & 230 & $26.2 \%$ \\
\hline White & 383 & $43.7 \%$ \\
\hline Body mass index $\left(\mathrm{kg} / \mathrm{m}^{2}\right)$ & 28.9 & $26.1-32.4$ \\
\hline \multicolumn{3}{|l|}{ Waist circumference (cm) } \\
\hline Men & 100.6 & $93.7-107.9$ \\
\hline Women & 96.9 & 89.8-106.8 \\
\hline Systolic blood pressure (mmHg) & 128.3 & $117.0-141.5$ \\
\hline Diastolic blood pressure (mmHg) & 78.0 & $71.0-85.0$ \\
\hline Raised blood pressure & 699 & $78.2 \%$ \\
\hline Duration of diabetes (years) & 6 & $3.0-12.0$ \\
\hline Self-referred insulin treatment & 131 & $15.6 \%$ \\
\hline $\begin{array}{l}\text { Self-referred oral hypoglycemic treatment } \\
\text { alone }\end{array}$ & 619 & $76.6 \%$ \\
\hline Self-referred statin treatment & 285 & $31.7 \%$ \\
\hline Self-referred use of other lipid-lowering drugs & 33 & $3.7 \%$ \\
\hline Glycated hemoglobin (\%) & 6.6 & $5.8-7.9$ \\
\hline Fasting glucose (mg/dL) & 150.0 & $123.0-198.0$ \\
\hline 2 h post-load glucose (mg/dL) & 200.0 & $146.0-274.0$ \\
\hline Glucose excursion $(\mathrm{mg} / \mathrm{dL})^{\dagger}$ & 44.0 & $15.0-76.0$ \\
\hline Fasting triglycerides (mg/dL) & 140.0 & 103.0-199.0 \\
\hline 2 h post-load triglycerides (mg/dL) & 172.0 & $128.0-237.0$ \\
\hline Triglyceride excursion $(\mathrm{mg} / \mathrm{dL})^{\dagger}$ & 26.0 & $11.0-45.0$ \\
\hline Fasting insulin $(\mu \mathrm{U} / \mathrm{mL})^{\ddagger}$ & 8.8 & $5.1-13.9$ \\
\hline Cholesterol (mg/dL) & 199.0 & $173.0-231.0$ \\
\hline HDL-cholesterol (mg/dL) & 49.0 & $42.0-59.0$ \\
\hline LDL-cholesterol (mg/dL) & 116.0 & $94.0-142.0$ \\
\hline Postural hypotension & 23 & $2.6 \%$ \\
\hline \multicolumn{3}{|l|}{ Self-reported } \\
\hline Stroke & 22 & $2.5 \%$ \\
\hline Heart failure & 43 & $4.8 \%$ \\
\hline Angina & 66 & $7.4 \%$ \\
\hline Myocardial infarction & 51 & $5.7 \%$ \\
\hline Coronary disease & 108 & $12.0 \%$ \\
\hline Any cardiovascular complication & 148 & $16.5 \%$ \\
\hline
\end{tabular}

ELSA-Brasil, 2008-2010.

Small variations in the total number of individuals are due to missing data.

${ }^{+} 2 \mathrm{~h}$ post-load level minus fasting level.

${ }^{\ddagger}$ Only among those not on insulin use $(n=683)$.

glycated hemoglobin $(\mathrm{r}=0.53, \mathrm{p}<0.01)$. Lesser correlations were observed with duration of diabetes $(r=0.34$, $\mathrm{p}<0.01)$, waist-hip ratio $(\mathrm{r}=0.16, \mathrm{p}<0.01)$, systolic blood pressure $(\mathrm{r}=0.17 \mathrm{p}<0.01)$ and age $(\mathrm{r}=0.11, \mathrm{p}<0.01)$. Correlations for triglyceride excursion were generally weaker, with no correlation being observed with fasting triglycerides and a moderate correlation with post-load triglycerides $(\mathrm{r}=0.34, \mathrm{p}<0.01)$. Weak correlations were present with fasting glucose $(\mathrm{r}=0.11, \mathrm{p}<0.01)$, post-load glucose $(r=0.09, p<0.01)$, glycated hemoglobin $(r=0.12$, $\mathrm{p}<0.01)$ and fasting insulin $(\mathrm{r}=0.09, \mathrm{p}<0.01)$, as illustrated in Table 2.

In crude analyses (Table 3), the magnitude of the glucose excursions varied with several clinical characteristics. Higher glucose excursions were found among those with $\mathrm{HbA} 1_{\mathrm{C}}$ values greater than $7 \%$, use of insulin, postural hypotension, and self-reported cardiovascular comorbidity. Lower excursions were found among those with abdominal obesity and also those receiving only oral hypoglycemic treatment. No statistically significant associations were seen with triglyceride excursions.

Table 4 shows analyses of glucose and triglyceride excursions with adjustment for covariates. In the more adjusted analysis, glucose excursion was $7.6 \mathrm{mg} / \mathrm{dL}$ greater in whites, $6.1 \mathrm{mg} / \mathrm{dL}$ greater for each 10 years increase in age; $4.5 \mathrm{mg} / \mathrm{dL}$ greater for each five year increase in duration of diabetes; $10.7 \mathrm{mg} / \mathrm{dL}$ greater for each $1 \%$ increase of glycated hemoglobin; and $44 \mathrm{mg} / \mathrm{dL}$ greater in the presence of insulin use. Glucose excursion decreased by $5.6 \mathrm{mg} / \mathrm{dL}$ for each $5 \mathrm{~kg} / \mathrm{m}^{2}$ increase in body mass index. For triglyceride excursions, as in the crude analyses, no variation in magnitude was observed according to the factors analyzed.

Table 5 presents the associations of glucose and triglyceride excursions with cardiovascular comorbidities, when adjusted through logistic regression. The results are presented both globally and with participants stratified into obese and non-obese categories, and odds ratios are expressed for a change of $25 \mathrm{mg} / \mathrm{dL}$ in glucose and triglyceride excursions. Covariate control was limited given the small number of outcomes observed. In this regard, only age-adjusted models are presented for the more specific outcomes (myocardial infarction, angina, stroke, and heart failure). Associations for the total sample for both glucose and triglyceride excursions were minimal. However, when the associations were investigated in subgroups, a relatively consistent pattern of small though generally not statistically significant associations was frequently seen for obese individuals. With the exception of stroke, the outcome with fewest cases, all associations were stronger among the obese, the excursion - obesity interaction being statistically significant for the triglyceride excursion for many of the outcomes.

In multiply-adjusted analyses in the obese strata, the presence of any cardiovascular comorbidity was $12 \%(-8 \%$ to $36 \%$ ) more frequent for every $25 \mathrm{mg} / \mathrm{dL}$ greater glucose 
Table 2 Spearman correlation coefficients between clinical and laboratory variables in patients with diabetes during a test meal $(\mathbf{n}=\mathbf{8 9 8})$

\begin{tabular}{|c|c|c|c|c|c|c|}
\hline & $\begin{array}{l}\text { Fasting } \\
\text { glucose }\end{array}$ & $\begin{array}{l}\text { Post-load } \\
\text { glucose }\end{array}$ & $\begin{array}{l}\text { Glucose } \\
\text { excursion }\end{array}$ & $\begin{array}{l}\text { Fasting } \\
\text { triglycerides }\end{array}$ & $\begin{array}{l}\text { Post-load } \\
\text { triglycerides }\end{array}$ & $\begin{array}{l}\text { Triglyceride } \\
\text { excursion }^{+}\end{array}$ \\
\hline Fasting glucose & - & $0.83^{* *}$ & $0.43^{* *}$ & $0.26^{* *}$ & $0.29^{* *}$ & $0.11^{* *}$ \\
\hline Post-load Glucose & $0.83^{* *}$ & - & $0.83^{* *}$ & $0.19^{* *}$ & $0.22^{* *}$ & $0.09^{* *}$ \\
\hline Glucose excursion & $0.43^{* *}$ & $0.83^{* *}$ & - & 0.05 & $0.08^{*}$ & 0.04 \\
\hline Fasting triglycerides & $0.26^{* *}$ & $0.19^{* *}$ & 0.05 & - & $0.94^{* *}$ & 0.06 \\
\hline Post-load Triglycerides & $0.29^{* *}$ & $0.22^{* *}$ & 0.08 & $0.94^{* *}$ & - & $0.34^{* *}$ \\
\hline Triglyceride excursion & $0.11^{* *}$ & $0.09^{* *}$ & 0.04 & 0.06 & $0.34^{* *}$ & - \\
\hline Glycated hemoglobin & $0.73^{* *}$ & $0.76^{* *}$ & $0.53^{* *}$ & $0.15^{* *}$ & $0.20^{* *}$ & $0.12^{* *}$ \\
\hline Fasting insulin & $-0.07^{*}$ & -0.01 & 0.05 & $0.20^{* *}$ & $0.21^{* *}$ & $0.09^{* *}$ \\
\hline C-reative Protein & $0.13^{* *}$ & $0.12^{* *}$ & 0.06 & $0.11^{* *}$ & $0.11^{* *}$ & 0.05 \\
\hline Age & $-0.08^{*}$ & -0.01 & $0.11^{* *}$ & $-0.09^{*}$ & $-0.10^{*}$ & -0.05 \\
\hline Body mass index & 0.04 & -0.01 & -0.06 & $0.20^{* *}$ & $0.18^{* *}$ & 0.04 \\
\hline Waist circumference & $0.11^{* *}$ & $0.07^{*}$ & -0.01 & $0.22^{* *}$ & $0.20^{* *}$ & 0.01 \\
\hline Waist to hip ratio & $0.20^{* *}$ & $0.21^{* *}$ & $0.16^{* *}$ & $0.25^{* *}$ & $0.23^{* *}$ & -0.01 \\
\hline Duration of Diabetes & $0.16^{* *}$ & $0.31^{* *}$ & $0.34^{* *}$ & -0.05 & -0.06 & -0.06 \\
\hline Systolic blood pressure & $0.22^{* *}$ & $0.22^{* *}$ & $0.17^{* *}$ & $0.09^{* *}$ & $0.09^{* *}$ & 0.02 \\
\hline Diastolic blood pressure & $0.24^{* *}$ & $0.17^{* *}$ & $0.07^{*}$ & $0.11^{* *}$ & $0.12^{* *}$ & 0.04 \\
\hline
\end{tabular}

ELSA-Brasil, 2008-2010.

${ }^{\dagger}$ Two-hour post-load level minus fasting level; ${ }^{*} \mathrm{P}<0.05$; ${ }^{* *} \mathrm{P}<0.01$.

excursion, and $15 \%$ ( $-7 \%$ to $43 \%)$ more frequent for every $25 \mathrm{mg} / \mathrm{dL}$ greater triglyceride excursion. In this strata, an increase in the glucose excursion of this magnitude was associated with a $32 \%$ increase in the age-adjusted risk of having had a myocardial infarction $(\mathrm{OR}=1.32,95 \% \mathrm{CI}$ 01.03 to 1.68$)$, and an increase in the triglyceride excursion of this magnitude with a $36 \%$ increase in the ageadjusted risk of having a history of angina $(\mathrm{OR}=1.36,95 \%$ CI 1.01 to 1.83 ).

\section{Discussion}

The metabolic response to a test meal of approximately $450 \mathrm{kcal}$, roughly equivalent to a breakfast meal, led to $2 \mathrm{~h}$ glucose and triglyceride values $30 \%$ and $20 \%$ above those of fasting. However, the excursions varied widely, with those in the 75th percentile having an excursion approximately four times that of those in the 25th percentile for both glucose and triglycerides. Clinical correlates of a greater glucose excursion suggest that it reflects a decreased capacity for insulin secretion, whereas no correlates of the triglyceride excursion were identified. In overall analyses, no associations were found between a greater excursion and a history of cardiovascular comorbidity. However, the relative risk of presenting a comorbidity with a larger excursion was generally greater in the obese, though this risk was never of a large magnitude.

The major predictors of greater glycemic excursion greater age, duration of diabetes, glycated hemoglobin and, especially, the use of insulin - suggest that the main determinant of the post meal blood glucose excursion was a relative insulin deficiency. That obesity associated with a lesser excursion perhaps similarly reflects greater preservation of the capacity for insulin secretion. Individuals with a greater excursion are presumably further along the progressive course of beta-cell dysfunction which characterizes the natural history of type 2 diabetes [18]. Bonora et al. [19] when evaluating cross-sectional associations of blood glucose two hours after breakfast, lunch, and dinner, measured at home in 3,284 diabetic subjects, found similarly that age and diabetes duration were associated with greater excursions, and obesity with lesser ones.

On the other hand, the larger associations with clinical outcomes found in obese individuals suggest that the clinical impact of glycemic and triglyceride excursions may be greater for these individuals. This finding is consistent with the previous finding of a greater association of rapidly absorbed carbohydrate in the diet with circulating levels of C-reactive protein [20].

Few previous studies have evaluated the impact of postprandial blood glucose excursions on cardiovascular outcomes. Cavalot et al. [8] followed 529 individuals with diabetes for an average period of five years after a single profile of glucose values pre- and post-meals, and demonstrated that hyperglycemia, measured two hours after lunch, but not pre-meal measures, was an independent risk factor for cardiovascular events (third vs. 
Table 3 Difference between glucose and triglycerides excursions in individuals with diabetes according to clinical and laboratory characteristics $(\mathbf{n}=\mathbf{8 9 8})$

\begin{tabular}{|c|c|c|c|c|c|c|}
\hline & $\begin{array}{l}\text { Glucose excursion } \\
\text { (mg/dL) }\end{array}$ & $95 \% \mathrm{Cl}$ & $\mathbf{P}$ & $\begin{array}{l}\text { Triglycerides excursion } \\
\text { (mg/dL) }\end{array}$ & $95 \% \mathrm{Cl}$ & $\mathbf{P}$ \\
\hline \multicolumn{7}{|c|}{ Obesity (BMl $\geq 30 \mathrm{~kg} / \mathrm{m}^{2}$ ) } \\
\hline Yes & 49.2 & $44.3 ; 54.2$ & 0.26 & 27.8 & $23.7 ; 31.8$ & 0.74 \\
\hline No & 52.2 & $48.0 ; 56.4$ & & 26.9 & $23.4 ; 30.3$ & \\
\hline \multicolumn{7}{|c|}{ Abdominal obesity } \\
\hline Yes & 48.8 & $44.8 ; 52.9$ & 0.10 & 28.3 & $25.0 ; 31.7$ & 0.31 \\
\hline No & 54.3 & $49.2 ; 59.4$ & & 25.8 & $21.4 ; 29.8$ & \\
\hline \multicolumn{7}{|c|}{$\mathrm{A} 1 \mathrm{C}>7 \%$} \\
\hline Yes & 75.9 & $71.5 ; 80.4$ & $<0.001$ & 27.5 & $23.5 ; 31.6$ & 0.86 \\
\hline No & 33.2 & $29.4 ; 37.0$ & & 27.1 & $23.6 ; 30.5$ & \\
\hline \multicolumn{7}{|c|}{ Oral hypoglycemic treatment (without insulin) } \\
\hline Yes & 46.1 & $42.3 ; 49.8$ & $<0.001$ & 27.9 & $24.7 ; 31.1$ & 0.17 \\
\hline No & 75.5 & $68.8 ; 82.3$ & & 23.3 & $17.5 ; 29.1$ & \\
\hline \multicolumn{7}{|c|}{ Insulin use } \\
\hline Yes & 96.7 & $88.9 ; 104.4$ & $<0.001$ & 21.2 & $14.3 ; 28.2$ & 0.09 \\
\hline No & 44.6 & $41.3 ; 48.0$ & & 27.9 & $24.9 ; 30.9$ & \\
\hline \multicolumn{7}{|c|}{ Postural hypotension } \\
\hline Yes & 82.0 & $62.1 ; 101.8$ & 0.001 & 29.8 & $13.1 ; 46.4$ & 0.77 \\
\hline No & 49.8 & $46.5 ; 53.0$ & & 27.3 & $24.6 ; 30.0$ & \\
\hline \multicolumn{7}{|c|}{ Any cardiovascular complication } \\
\hline Yes & 63.7 & $55.9 ; 71.5$ & 0.001 & 27.0 & $20.6 ; 33.4$ & 0.94 \\
\hline No & 48.4 & $45.0 ; 51.2$ & & 27.3 & $24.5 ; 30.2$ & \\
\hline \multicolumn{7}{|c|}{ Myocardial infarction } \\
\hline Yes & 72.7 & $59.4 ; 86.0$ & 0.001 & 29.9 & $19.1 ; 40.8$ & 0.62 \\
\hline No & 49.7 & $46.4 ; 52.9$ & & 27.1 & $24.4 ; 29.8$ & \\
\hline \multicolumn{7}{|l|}{ Angina } \\
\hline Yes & 61.3 & $49.5 ; 73.0$ & 0.07 & 27.6 & $17.9 ; 37.2$ & 0.96 \\
\hline No & 50.0 & $46.8 ; 53.4$ & & 27.3 & $24.6 ; 30.0$ & \\
\hline \multicolumn{7}{|c|}{ Heart failure } \\
\hline Yes & 65.7 & $51.1 ; 80.2$ & 0.04 & 28.6 & $16.8 ; 40.4$ & 0.82 \\
\hline No & 50.2 & $47.0 ; 53.5$ & & 27.2 & $24.5 ; 29.9$ & \\
\hline \multicolumn{7}{|c|}{ Coronary disease } \\
\hline Yes & 63.5 & $54.4 ; 72.7$ & 0.004 & 27.6 & $20.1 ; 35.2$ & 0.91 \\
\hline No & 49.2 & $45.9 ; 52.6$ & & 27.2 & $24.4 ; 30.0$ & \\
\hline \multicolumn{7}{|l|}{ Stroke } \\
\hline Yes & 74.6 & $54.3 ; 94.9$ & 0.02 & 23.9 & $7.0 ; 40.7$ & 0.69 \\
\hline No & 50.4 & $47.1 ; 53.6$ & & 27.3 & $24.7 ; 30.0$ & \\
\hline \multicolumn{7}{|c|}{ Raised blood pressure } \\
\hline Yes & 51.9 & $48.3 ; 55.5$ & 0.32 & 26.9 & $23.9 ; 29.9$ & 0.73 \\
\hline No & 50.3 & $41.2 ; 54.8$ & & 28.0 & $22.4 ; 33.7$ & \\
\hline \multicolumn{7}{|c|}{ Hypertriglyceridemia } \\
\hline Yes & 50.6 & $45.9 ; 55.3$ & 0.84 & 27.2 & $23.3 ; 31.1$ & 0.98 \\
\hline No & 51.3 & $46.9 ; 55.6$ & & 27.3 & $23.7 ; 30.8$ & \\
\hline
\end{tabular}


Table 3 Difference between glucose and triglycerides excursions in individuals with diabetes according to clinical and laboratory characteristics $(\mathbf{n}=\mathbf{8 9 8})$ (Continued)

\begin{tabular}{llllll}
\hline Low HDL-C & & & & & \\
Yes & 49.0 & $43.2 ; 54.9$ & 0.44 & 28.9 & $24.1 ; 33.6$ \\
No & 51.8 & $48.0 ; 55.6$ & & 26.5 & $23.4 ; 29.7$ \\
\hline
\end{tabular}

ELSA-Brasil, 2008-2010.

first tertile HRs $5.54,95 \%$ CI 1.45 to 21.20 in women and $2.12,95 \%$ CI 1.04 to 4.32 in men). In a later study, the same authors [9] followed 505 of these individuals with diabetes for about 14 years and assessed the relationship of postprandial glycemia with mortality. Hyperglycemia two hours after lunch was identified as an independent risk factor for cardiovascular mortality (individuals with postprandial glucose $\geq 180 \mathrm{mg} / \mathrm{dL}$ vs. $<180 \mathrm{mg} / \mathrm{dL}, \mathrm{HR}=1.45,95 \% \mathrm{CI}: 1.06$ to 1,99$)$ and overall mortality ( $\mathrm{HR}=1.85,95 \% \mathrm{CI}: 1.31$ to 2.61 ).

Clinical trials aimed at minimizing postmeal glucose peaks have produced mixed findings in terms of the association of greater excursions with cardiovascular outcomes. Esposito et al. [21] randomized 175 patients to repaglinide or gyburide and subsequently followed them for 12 months, finding that post-prandial peaks were smaller (148 vs. $180 \mathrm{mg} / \mathrm{dL}$ ), C-reactive protein and IL-6 lower, and the frequency of carotid artery intimal-media thickness regression greater $(52 \%$ vs. $18 \%)$ in the repaglinide group, despite similar levels of $\mathrm{HbA1}_{\mathrm{C}}$. On the other hand, lesser within day glucose variability was not associated with a reduction in cardiovascular events in a clinical trial investigating lispro (vs. NPH) insulin as a strategy to diminish postprandial glucose peaks [22]. However, the lispro intervention in this trial proved ineffective in significantly altering intraday variability, and the trial, stopped early for futility, and was of a relatively short duration.

Oxidative stress and inflammation have been suggested as potential mediators that could link postprandial hyperglycemia, in part through endothelial dysfunction [23-25], to diabetes complications [26-28] although the association of greater peaks with oxidative stress remains to be clearly established [29]. Individuals with diabetes tend to exhibit high levels of adhesion molecule markers of endothelial dysfunction - ICAM-1, VCAM-1 and E-selectin [30]. These markers, along with those of oxidative stress, increase after a test meal composed of fats (65 grams),

Table 4 Adjusted $^{\dagger}$ differences between glucose and triglyceride excursions in individuals with diabetes $(n=898)$

\begin{tabular}{|c|c|c|c|c|c|c|}
\hline \multirow[t]{2}{*}{ Glucose excursion } & \multicolumn{3}{|c|}{ Model 1} & \multicolumn{3}{|c|}{ Model 2} \\
\hline & $\mathrm{mg} / \mathrm{dL}$ & $95 \% \mathrm{Cl}$ & $\mathrm{p}$ & $\mathrm{mg} / \mathrm{dL}$ & $95 \% \mathrm{Cl}$ & $\mathrm{p}$ \\
\hline Race (white vs. non-white) & 5.3 & $-0.5 ; 11.1$ & 0.07 & 7.6 & $1.9 ; 13.3$ & 0.01 \\
\hline Sex (male vs. female) & -5.2 & $-10.9 ; 0.5$ & 0.07 & -2.1 & $-7.8 ; 3.5$ & 0.45 \\
\hline Age (10 years) & 8.4 & $4.9 ; 11.8$ & $<0.001$ & 6.1 & $2.5 ; 9.6$ & $<0.001$ \\
\hline Glycated hemoglobin (\%) & 13.3 & $11.7 ; 14.9$ & $<0.001$ & 10.7 & $9.1 ; 12.3$ & $<0.001$ \\
\hline Body mass index $\left(5 \mathrm{~kg} / \mathrm{m}^{2}\right)$ & & & & -5.6 & $-8.4 ;-2.8$ & $<0.001$ \\
\hline Duration of diabetes (5 years) & & & & 4.5 & $2.6 ; 6.4$ & $<0.001$ \\
\hline Other medication for diabetes (yes vs. no) & & & & 9.4 & $-1.2 ; 20.1$ & 0.08 \\
\hline Insulin use (yes vs. no) & & & & 44.4 & $31.7 ; 57.1$ & $<0.001$ \\
\hline \multirow[t]{2}{*}{ Triglyceride excursion } & \multicolumn{3}{|c|}{ Model 1} & \multicolumn{3}{|c|}{ Model 2} \\
\hline & $\mathrm{mg} / \mathrm{dL}$ & $95 \% \mathrm{Cl}$ & $\mathrm{p}$ & $\mathrm{mg} / \mathrm{dL}$ & $95 \% \mathrm{Cl}$ & $\mathrm{p}$ \\
\hline Race (white vs.non-white) & 3.3 & $-2.2 ; 8.8$ & 0.24 & 3.7 & $-2.1 ; 9.6$ & 0.21 \\
\hline Sex (male vs. female) & 2.1 & $-3.3 ; 7.5$ & 0.45 & 3.0 & $-2.9 ; 8.7$ & 0.33 \\
\hline Age (10 years) & -2.8 & $-6.1 ; 0.4$ & 0.09 & -3.3 & $-7,0 ; 0.3$ & 0.07 \\
\hline Glycated hemoglobin (\%) & 0.87 & $-0.8 ; 2.2$ & 0.33 & 0.6 & $-1.1 ; 2.3$ & 0.48 \\
\hline Body mass index $\left(5 \mathrm{~kg} / \mathrm{m}^{2}\right)$ & & & & 1.0 & $-1.9 ; 3.9$ & 0.51 \\
\hline Duration of diabetes (5 years) & & & & 0.2 & $-1.8 ; 2.3$ & 0.82 \\
\hline Other medication for diabetes (yes vs. no) & & & & -1.3 & $-12.3 ; 9.8$ & 0.82 \\
\hline Insulin use (yes vs. no) & & & & -8.1 & $-21.3 ; 5.0$ & 0.22 \\
\hline
\end{tabular}


Table 5 Adjusted $^{\dagger}$ associations of glucose and triglyceride excursions (of $25 \mathrm{mg} / \mathrm{dL}$ ) with clinical outcomes ( $\mathrm{n}=\mathbf{8 9 8}$ )

\begin{tabular}{|c|c|c|c|c|c|c|c|c|c|c|c|}
\hline \multirow[t]{2}{*}{ Glucose excursion } & \multirow[t]{2}{*}{ Model } & \multicolumn{3}{|c|}{ Global } & \multicolumn{3}{|c|}{ Obese $(n=375)$} & \multicolumn{3}{|c|}{ Non-obese $(n=523)$} & \multirow{2}{*}{$\begin{array}{l}\text { Interaction } \\
\mathbf{p}\end{array}$} \\
\hline & & OR & $95 \% \mathrm{Cl}$ & $p$ & OR & $95 \% \mathrm{Cl}$ & $p$ & OR & $95 \% \mathrm{Cl}$ & $p$ & \\
\hline \multirow[t]{2}{*}{ Any cardiovascular complication } & 1 & 1.15 & $(1.06-1.25)$ & $<0.01$ & 1.19 & $(1.01-1.39)$ & 0.04 & 1.15 & $(1.03-1.27)$ & 0.01 & 0.86 \\
\hline & 2 & 1.06 & $(0.95-1.17)$ & 0.32 & 1.12 & $(0.92-1.36)$ & 0.26 & 1.03 & $(0.89-1.19)$ & 0.94 & 0.35 \\
\hline \multirow[t]{2}{*}{ Heart disease } & 1 & 1.13 & $(1.03-1.25)$ & 0.01 & 1.22 & $(1.03-1.46)$ & 0.02 & 1.10 & $(0.98-1.25)$ & 0.11 & 0.38 \\
\hline & 2 & 1.04 & $(0.91-1.18)$ & 0.57 & 1.20 & $(0.96-1.50)$ & 0.12 & 0.96 & $(0.82-1.14)$ & 0.65 & 0.11 \\
\hline Myocardial infarction & 1 & 1.21 & $(1.06-1.38)$ & $<0.01$ & 1.32 & $(1.03-1.68)$ & 0.03 & 1.17 & $(1.00-1.36)$ & 0.05 & 0.42 \\
\hline Angina & 1 & 1.11 & $(0.99-1.25)$ & 0.09 & 1.21 & $(0.99-1.48)$ & 0.06 & 1.07 & $(0.92-1.25)$ & 0.41 & 0.36 \\
\hline Stroke & 1 & 1.23 & $(1.02-1.48)$ & 0.03 & 1.08 & $(0.63-1.84)$ & 0.78 & 1.25 & $(1 .-1.47)$ & 0.05 & 0.50 \\
\hline Heart failure & 1 & 1.15 & $(1.00-1.33)$ & 0.06 & 1.19 & $(0.93-1.52)$ & 0.16 & 1.15 & $(0.95-1.38)$ & 0.15 & 0.90 \\
\hline \multirow[t]{2}{*}{ Triglyceride excursion } & & \multicolumn{3}{|c|}{ Global } & \multicolumn{3}{|c|}{ Obese $(n=375)$} & \multicolumn{3}{|c|}{ Non-obese $(n=523)$} & Interaction $^{\ddagger}$ \\
\hline & & OR & $95 \% \mathrm{Cl}$ & $p$ & OR & $95 \% \mathrm{Cl}$ & $\mathrm{p}$ & $\overline{\mathrm{OR}}$ & $95 \% \mathrm{Cl}$ & $p$ & $p$ \\
\hline \multirow[t]{2}{*}{ Any cardiovascular complication } & 1 & 1.00 & $(0.90-1.12)$ & 0.94 & 1.11 & $(0.91-1.35)$ & 0.32 & 0.93 & $(0.81-1.08)$ & 0.34 & 0.15 \\
\hline & 2 & 1.01 & $(0.90-1.13)$ & 0.87 & 1.15 & $(0.93-1.43)$ & 0.20 & 0.91 & $(0.78-1.06)$ & 0.21 & 0.06 \\
\hline \multirow[t]{2}{*}{ Heart disease } & 1 & 1.02 & $(0.89-1.16)$ & 0.80 & 1.23 & $(0.96-1.58)$ & 0.10 & 0.91 & $(0.78-1.07)$ & 0.24 & 0.04 \\
\hline & 2 & 1.02 & $(0.90-1.17)$ & 0.72 & 1.25 & $(0.95-1.63)$ & 0.11 & 0.91 & $(0.77-1.07)$ & 0.24 & 0.04 \\
\hline Myocardial infarction & 1 & 1.07 & $(0.87-1.32)$ & 0.52 & 1.12 & $(0.79-1.59)$ & 0.53 & 1.05 & $(0.80-1.36)$ & 0.73 & 0.79 \\
\hline Angina & 1 & 1.01 & $(0.85-1.19)$ & 0.93 & 1.36 & $(1.01-1.83)$ & 0.04 & 0.86 & $(0.72-1.02)$ & 0.09 & 0.01 \\
\hline Stroke & 1 & 0.96 & $(0.76-1.21)$ & 0.75 & 0.89 & $(0.64-1.24)$ & 0.49 & 0.98 & $(0.72-1.33)$ & 0.92 & 0.76 \\
\hline Heart failure & 1 & 1.03 & $(0.84-1.27)$ & 0.76 & 1.09 & $(0.79-1.49)$ & 0.60 & 0.97 & $(0.75-1.26)$ & 0.84 & 0.56 \\
\hline
\end{tabular}

ELSA-Brasil, 2008-2010.

${ }^{\dagger}$ Through logistic regression, as follows:

Model 1: age.

Model 2: model $1+$ sex, glycated hemoglobin, duration of diabetes, use of insulin.

${ }^{\ddagger}$ Excursion versus obesity interaction.

glucose (75 grams), or the two together [31], this latter combination producing a greater effect than either of its parts in isolation.

Other studies have found a relationship between postprandial triglycerides and the complications of diabetes and/or risk factors for these complications. The triglyceride excursion after consumption of a test meal $\left(729 \mathrm{kcal} / \mathrm{m}^{2} ; 65.2\right.$ grams of fat, 24.75 grams of carbohydrates) has been shown to be higher in individuals with diabetes; and among those with diabetes, to take longer to return to baseline in those who already have macrovascular complications [32]. Coutinho et al. [33] found that, in addition to an increase in triglyceride levels, consumption of a test meal rich in fat $(682.6 \mathrm{kcal}, 56.1$ grams of fat, 34.4 grams of carbohydrates) was associated with an increase in blood leukocytes and a decrease in HDL-cholesterol. Teno et al. [11], in turn, found an association of postprandial triglyceride levels (following a standardized $9 \mathrm{kcal} / \mathrm{kg}$ meal) with the carotid intimamedia thickness of patients with diabetes. Non-fasting triglycerides have been shown to predict cardiovascular events, especially in women [34]. We did not demonstrate any relationship of triglycerides (fasting, post-meal or excursion) with cardiovascular comorbidities, perhaps because our postprandial measure was two hours following meal consumption, too early to detect the triglyceride peak, which generally occurs four hours after consumption [35].

The recommended daily energy intake for our study participants (based on being sedentary with a median weight, height, and age) was $2310 \mathrm{kcal}$ for men and $1755 \mathrm{kcal}$ for women [36]. Nutritional recommendations generally allocate $20 \%$ of total energy intake to breakfast [37]. For our subjects, this would be $460 \mathrm{kcal}$ to men and $351 \mathrm{kcal}$ to women, approximately equal to the test meal used in our study $-454.8 \mathrm{kcal}$. This load, compared to others found in the literature, is small, but was adopted as it approximated what participants would be possibly taking in early morning if not being examined in our clinics, was easily standardized and was available at all investigation centers. Two of the test meal studies cited above used a load according to the body surface area which ranged from $700 \mathrm{kcal} / \mathrm{m}^{2}$ [31] to $730 \mathrm{kcal} / \mathrm{m}^{2}$ [32], resulting in 1211 to $1263 \mathrm{kcal}$ load for a $1.73 \mathrm{~m}^{2}$ individual. As our participants median body surface area was $1.84 \mathrm{~m}^{2}$, this would translate to $1288 \mathrm{kcal}$ to $1343 \mathrm{kcal}$. Others determined the load based on weight, and ranged from $9 \mathrm{kcal} / \mathrm{kg}$ [11] to $30 \mathrm{kcal} / \mathrm{kg}$ [38], equivalent to a 630 to $2100 \mathrm{kcal}$ load for a $70 \mathrm{~kg}$ individual. Still others, which, like ours, 
used a standardized fixed test meal, also provided a higher number of calories, ranging from 500 [33] to $1480 \mathrm{kcal}$ [39].

The relatively low energy intake in our study may thus have underestimated the true effect of usual postprandial glycemia in these mostly obese patients, especially if lunch and dinner meals are considered. Given that the caloric and fat content of meals usually taken by the overweight or obese are considerably greater than those we studied, it is likely that usual changes in blood glucose and triglycerides will be outside of the range we studied.

Another possible explanation for the small size of associations found with comorbidities was the source of saturated fat in the test meal of our study - dairy products. Higher consumption of saturated fats from dairy products, as assessed by a food frequency questionnaire, has been associated with lower risk of cardiovascular events $(\mathrm{HR}=$ 0.79, 95\% CI: 0.68 to 0.92 , for each increase of 5 grams/ day) while consumption of saturated fat from meat is associated with an increased risk $(\mathrm{HR}=1.26,95 \% \mathrm{CI}$ : 1.02 1.54 , for each increase of 5 grams/day) [40]. Further, individuals already with prevalent comorbidity may have dampened their excursions through medication use, thus minimizing the associations we found.

It is also important to consider that both fasting and post-load glucose measures are extremely variable, not only between individuals, but also over time in a given individual [41]. As our study performed only a single measurement of plasma glucose and triglycerides, it cannot be expected to capture this biological variation, thus also potentially decreasing the size of associations seen $[42,43]$.

In summary, a relatively small test meal, composed of foods common to breakfast with rapidly absorbed carbohydrate and saturated fat, produced variable postload excursions in a large sample of diabetic subjects, the magnitude of the glycemic excursions being correlated with factors suggesting insulin insufficiency. Though no associations with the presence of diabetes complications were found, small and at times statistically significant associations of greater excursions with comorbidity were seen in those with obesity. These findings suggest that postprandial excursions resulting from intake of rapidly absorbed carbohydrate and saturated fat of this magnitude, though perhaps without impact on diabetes complications in the non-obese, may be of importance in obese subjects with a lesser capacity for insulin secretion.

\section{Competing interest}

The authors declare that they have no competing of interest.

\section{Authors' contributions}

BPR researched data and wrote the manuscript; $V C L$ contributed to the conception and design, researched data and wrote the manuscript; CDC researched data, reviewed/edited the manuscript; LOC contributed to the discussion and reviewed/edited the manuscript; MIS contributed to the conception and design, contributed to the discussion and reviewed/edited the manuscript; SMB contributed to the conception and design, reviewed/ edited the manuscript; MFS reviewed/edited the manuscript; SMA, reviewed/ edited the manuscript; BBD contributed to the conception and design, wrote the manuscript and reviewed/edited the manuscript. All authors read and approved the final manuscript.

\section{Acknowledgements}

We wish to thank all participants of ELSA-Brasil who collaborated in this study. ELSA-Brasil was funded by the Ministry of Health (Department of Science and Technology), and the Ministry of Science, Technology and Innovation (through both the Financier of Studies and Projects and the Council for Scientific and Technological Development), processes: 0106 0010.00 RS, 0106 0212.00BA, 01060300.00 ES, 01060278.00 MG, 0106 0115.00SP, $01060071.00 \mathrm{RJ}$

\section{Author details}

${ }^{1}$ Graduate Studies Program in Epidemiology, School of Medicine, Federal University of Rio Grande do Sul, Porto Alegre, RS, Brazil. '2Food and Nutrition Research Center, Hospital de Clínicas de Porto Alegre, Federal University of Rio Grande do Sul, Rua Ramiro Barcelos 2600/419, Porto Alegre, RS 90035-003, Brazil. ${ }^{3}$ National School of Public Health, Oswaldo Cruz Foundation, Rio de Janeiro, RJ, Brazil. ${ }^{4}$ Graduate Studies Program in Public Health, Faculty of Medicine, Federal University of Minas Gerais, Belo Horizonte, MG, Brazil. ${ }^{5}$ Internal Medicine Department, Faculty of Medicine, Federal University of Minas Gerais, Belo Horizonte, MG, Brazil. ${ }^{6}$ Institute of Collective Health, Universidade Federal da Bahia, Salvador, Brazil.

Received: 18 November 2014 Accepted: 22 January 2015

Published online: 13 February 2015

\section{References}

1. International Diabetes Federation. International diabetes federation. 6th ed. Brussels, Belgium: IDF Diabetes Atlas; 2013. http://www.idf.org/diabetesatlas.

2. Fung TT, Schulze M, Manson JE, Willett WC, Hu FB. Dietary patterns, meat intake, and the risk of type 2 diabetes in women. Arch Int Med. 2004;64:2235-40.

3. Heidemann C, Schulze MB, Franco OH, van Dam RM, Mantzoros CS, Hu FB. Dietary patterns and risk of mortality from cardiovascular disease, cancer, and all causes in a prospective cohort of women. Circulation. 2008;118:230-7.

4. Mente A, de Koning L, Shannon HS, Anand SS. A systematic review of the evidence supporting a causal link between dietary factors and coronary heart disease. Arch Intern Med. 2009;169(7):659-69.

5. American Diabetes Association (ADA). Position statement: standards of medical care in diabetes - 2013. Diabetes Care. 2013;36(1):S11-66.

6. Ceriello A, Davidson J, Hanefeld M, Leiter L, Monnier L, Owens D, et al. International Prandial Glucose Regulation Study Group. Postprandial hyperglycaemia and cardiovascular complications of diabetes: an update. Nutr Metab Cardiovasc Dis. 2006;16:453-6.

7. 7.DECODE Study Group, the European Diabetes Epidemiology Group. Glucose tolerance and cardiovascular mortality: comparison of fasting and 2 hour diagnostic criteria. Arch Intern Med. 2001;161:397-405.

8. Cavalot F, Petrelli A, Traversa M, Bonomo K, Fiora E, Conti M, et al. Postprandial blood glucose is a stronger predictor of cardiovascular events than fasting blood glucose in type 2 diabetes mellitus, particularly in women: lessons from the San Luigi Gonzaga Diabetes Study. J Clin Endocrinol Metab. 2006;91(3):813-9.

9. Cavalot F, Pagliarino A, Valle M, Di Martino L, Bonomo K, Massucco P, et al. Postprandial blood glucose predicts cardiovascular events and all-cause mortality in type 2 diabetes in a 14-year follow-up: lessons from the San Luigi Gonzaga Diabetes Study. Diabetes Care. 2011;34(10):2237-43.

10. Ebenbichler CF, Kirchmair R, Egger C, Patsch JR. Postprandial state and atherosclerosis. Curr Opin Lipidol. 1995;6:286-90.

11. Teno $S$, Uto $Y$, Nagashima $H$, Endoh $Y$, Iwamoto $Y$, Omori $Y$, et al. Association of postprandial hypertriglyceridemia and carotid intima-media thickness in patients with type 2 diabetes. Diabetes Care. 2000;23:1401-6.

12. Schmidt MI, Duncan BB, Mill JG, Lotufo PA, Chor D, Barreto SM, et al. Cohort Profile: Longitudinal Study of Adult Health (ELSA-Brasil). Int J Epidemiol. 2014;0:1-8. 
13. Fedeli LG, Vidigal PG, Leite CM, Castilhos CD, Pimentel RA, Maniero VC, et al. Logistics of collection and transportation of biological samples and the organization of the central laboratory in the ELSA-Brasil. Rev Saúde Pública. 2013;47 Suppl 2:63-71.

14. Pereira AC, Bensenor IM, Fedeli LM, Castilhos C, Vidigal PG, Maniero V, et al. Design and implementation of the ELSA-Brasil biobank: a prospective study in a Brazilian population. Rev Saude Publica. 2013;47 Suppl 2:72-8.

15. Alberti KG, Eckel RH, Grundy SM, Zimmet PZ, Cleeman Jl, Donato KA, et al. Harmonizing the metabolic syndrome: a joint interim statement of the International Diabetes Federation Task Force on Epidemiology and Prevention; National Heart, Lung, and Blood Institute; American Heart Association; World Heart Federation; International Atherosclerosis Society; and International Association for the Study of Obesity. Circulation. 2009;120(16):1640-5.

16. National Cholesterol Education Program (NCEP). Third report-expert panel on detection, evaluation, and treatment of high blood cholesterol in adults (adult treatment panel III) final report. Circulation. 2002;106:3143-421.

17. Kaufmann $\mathrm{H}$. Consensus statement on the definition of orthostatic hypotension, pure autonomic failure and multiple system atrophy. Clin Auton Res. 1996;6(2):125-6.

18. Dailey G. New strategies for basal insulin treatment in type 2 diabetes mellitus. Clin Ther. 2004;26(6):889-901.

19. Bonora E, Corrao G, Bagnardi V, Ceriello A, Comaschi M, Montanari P, et al. Prevalence and correlates of post-prandial hyperglycaemia in a large sample of patients with type 2 diabetes mellitus. Diabetologia. 2006;49(5):846-54.

20. Liu S, Manson JE, Buring JE, Stampfer MJ, Willett WC, Ridker PM. Relation between a diet with a high glycemic load and plasma concentrations of high-sensitivity C-reactive protein in middle-aged women. Am J Clin Nutr. 2002;75(3):492-8

21. Esposito K, Giugliano D, Nappo F, Marfella R. Campanian Postprandial Hyperglycemia Study Group. Regression of carotid atherosclerosis by control of postprandial hyperglycemia in type 2 diabetes mellitus. Circulation. 2004;110(2):214-9.

22. Siegelaar $\mathrm{SE}$, Kerr $\mathrm{L}$, Jacober $\mathrm{SJ}$, Devries $\mathrm{JH}$. A decrease in glucose variability does not reduce cardiovascular event rates in type 2 diabetic patients after acute myocardial infarction: a reanalysis of the HEART2D study. Diabetes Care. 2011;34(4):855-7.

23. Matsumoto K, Sera Y, Ueki Y, Inukai G, Niiro E, Miyake S. Comparison of serum concentrations of soluble adhesion molecules in diabetic microangiopathy and macroangiopathy. Diabet Med. 2002;19:822-6.

24. Kowalska I, Straczkowski M, Szelachowska M, Kinalska I, Prokop J,

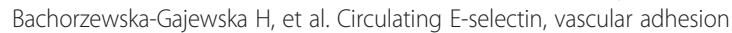
molecule-1, and intercellular adhesion molecule-1 in men with coronary artery disease assessed by angiography and disturbances of carbohydrate metabolism. Metabolism. 2002;51:733-6.

25. Rizzoni D, Muiesan ML, Porteri E, Castellano M, Salvetti M, Montero C, et al. Circulating adhesion molecules and carotid artery structural changes in patients with noninsulin-dependent diabetes mellitus. J Hum Hypertens. 2003;17:463-70.

26. Kitano D, Chiku M, Li Y, Okumura Y, Fukamachi D, Takayama T, et al. Miglitol improves postprandial endothelial dysfunction in patients with acute coronary syndrome and new-onset postprandial hyperglycemia. Cardiovasc Diabetol. 2013;12:92.

27. Cominacini L, Fratta Pasini A, Garbin U, Campagnola M, Davoli A, Rigoni A, et al. E-selectin plasma concentration is influenced by glycaemic control in NIDDM patients: possible role of oxidative stress. Diabetologia. 1997;40 (5):584-9.

28. Mohanty P, Hamouda W, Garg R, Aljada A, Ghanim H, Dandona P. Glucose challenge stimulates reactive oxygen species (ROS) generation by leucocytes. J Clin Endocrinol Metab. 2000;85(8):2970-3.

29. Siegelaar SE, Holleman F, Hoekstra JB, DeVries JH. Glucose variability; does it matter? Endocr Rev. 2010;31(2):171-82.

30. Steiner M, Reinhardt KM, Krammer B, Ernst B, Blann AD. Increased levels of soluble adhesion molecules in type 2 (non-insulin dependent) diabetes mellitus are independent of glycaemic control. Thromb Haemost. 1994;72(6):979-84.

31. Ceriello A, Quagliaro L, Piconi L, Assaloni R, Ros R, Maier A, et al. Effect of Postprandial hypertriglyceridemia and hyperglycemia on circulating adhesion molecules and oxidative stress generation and the possible role of simvastatin treatment. Diabetes. 2004;53:701-10.
32. Kumar V, Madhu SV, Singh G, Gambhir JK. Post-prandial hypertriglyceridemia in patients with type 2 diabetes mellitus with and without macrovascular disease. J Assoc Physicians India. 2010;58:603-7.

33. Coutinho ER, Macedo GM, Campos FS, Bandeira FA. Changes in HDL cholesterol and in the inflammatory markers of atherogenesis after an oral fat load in type-2 diabetic patients and normal individuals. Metab Syndr Relat Disord. 2008;6(2):153-7.

34. Nordestgaard BG, Benn M, Schnohr P, Tybjaerg-Hansen A. Nonfasting triglycerides and risk of myocardial infarction, ischemic heart disease, and death in men and women. JAMA. 2007;298(3):299-308.

35. Mero N, Malmström R, Steiner G, Taskinen MR, Syvänne M. Postprandial metabolism of apolipoprotein B-48- and B-100-containing particles in type 2 diabetes mellitus: relations to angiographically verified severity of coronary artery disease. Atherosclerosis. 2000;150(1):167-77.

36. Institute of Medicine. Dietary reference intakes for energy, carbohydrate fiber, fat, fatty acids, cholesterol, protein, and amino acids. Washington (DC): National Academy Press; 2005.

37. Assis M. A.A. Consulta de Nutrição: Controle e prevenção do colesterol elevado, Florianópolis. Insular; 1997. 168 p.

38. Sheu WH, Jeng CY, Lee WJ, Lin SY, Pei D, Chen YT. Simvastatin treatment on postprandial hypertriglyceridemia in type 2 diabetes mellitus patients with combined hyperlipidemia. Metabolism. 2001;50(3):355-9.

39. Anderson RA, Evans ML, Ellis GR, Graham J, Morris K, Jackson SK, et al. The relationships between post-prandial lipaemia, endothelial function and oxidative stress in healthy individuals and patients with type 2 diabetes. Atherosclerosis. 2001;154(2):475-83.

40. de Oliveira Otto MC, Mozaffarian D, Kromhout D, Bertoni AG, Sibley CT, Jacobs Jr DR, et al. Dietary intake of saturated fat by food source and incident cardiovascular disease: the Multi-Ethnic Study of Atherosclerosis. Am J Clin Nutr. 2012;96(2):397-404.

41. DeVries $\mathrm{JH}$. Glucose variability: where it is important and how to measure it. Diabetes. 2013;62(5):1405-8.

42. Chambless LE, Davis V. Analysis of associations with change in a multivariate outcome variable when baseline is subject to measurement error. Statist Med. 2003;22(7):1041-67.

43. Wolever TMS, Chiasson JL, Csima A. Variation of postprandial plasma glucose, palatability, and symptoms associated with a standardized mixed test meal versus $75 \mathrm{~g}$ oral glucose. Diabetes Care. 1998;21:336-40.

\section{Submit your next manuscript to BioMed Central and take full advantage of:}

- Convenient online submission

- Thorough peer review

- No space constraints or color figure charges

- Immediate publication on acceptance

- Inclusion in PubMed, CAS, Scopus and Google Scholar

- Research which is freely available for redistribution 